\title{
Assessment of Siosar's community sustainability in post-disaster relocation of Mount Sinabung eruption
}

\author{
Novi Kumalasari ${ }^{1, *}$, Linda Darmajanti ${ }^{2}$, and Sutopo Purwo Nugroho ${ }^{3}$ \\ ${ }^{1}$ School of Environmental Science, Universitas Indonesia, Indonesia \\ ${ }^{2}$ Department of Sociology, Faculty of Social and Political Science, Universitas Indonesia, Indonesia \\ ${ }^{3}$ Center for Data Information and Public Relation, National Disaster Management Authority, \\ Indonesia
}

\begin{abstract}
The practices and ways of humans interact with the environment will affect the sustainability of the society life. The achievement of a sustainability in a community in a certain place can be measured from the condition of balance of three important aspects which are ecological, social and spiritual aspects. Each region has a different level of sustainability. The purpose of this research is to analyze the sustainability level of the community resettlement from the Mount Sinabung eruption. The research was carried out in the Karos Siosar Relocation Area of North Sumatra. The Community Sustainability Assessment (CSA) method introduced by the Global Ecovillage Network/GEN is used to analyze its level of sustainability. The results of the research show that of the total value of each aspect is 523 which means showing a good start towards sustainability. However, when viewed from each aspect, the ecological aspect with a low value is 139 when compared to the other two aspects and shows the need for action in achieving sustainability. The social aspect obtained 208 values and spiritual aspects obtained 176 values, which shows that the people in the Siosar relocation area showed a good start towards sustainability.
\end{abstract}

\section{Introduction}

The eruption of Mount Sinabung since the first eruption on August 27, 2010 up until now has resulted in a series of natural phenomena, such as earthquakes, eruption cloud, lava flows, incandescent lava, flare stones and poisonous gases that bring disaster to the people living nearby [1]. After the occurrence of the danger that triggered the disaster, there were groups of people who are safe and survived. However, they must feel the impact not only on the physical aspect, but they can also face the potential for social impacts, such as stagnation in economic growth, weakening social relations, increasing poverty rates, loss of livelihoods and others [2,3]. There are several impact of Mount Sinabung Eruption, 16 people died, thousands of residences in the radius of 3-5 km and several villages outside the

\footnotetext{
*Corresponding author: novi.kumalasari@bnpb.go.id
} 
$5 \mathrm{~km}$ radius (31.379 peole/9915 families) were displaced, damage and losses were estimated at 1.80 trillion rupiah [4]. In restoring the livelihoods of people affected by disasters the government implemented rehabilitation and reconstruction carried out in several stages. In the first phase the government relocated 370 families to the Siosar area. The government has provided housing assistance and/or farming business to the 370 families and built an infrastructure such as clean water, electricity and communal septic tanks, places for praying, health centers, schools (elementary schools and preschool/PAUD), villages government offices, roads and provide transportation facilities from the relocation area to the district capital.

Siosar relocation area is administratively located in the District of Merk, Karo Regency, which is 12 kilometers south of Kabanjahe City, the Capital of Karo Regency. Based on land status, Siosar relocation area is a production forest has been converted into settlements and agriculture for community and the land must be be returned to the government within 20 years $[5,6]$. The relocation area is in the upstream area of two important and potential watersheds (daerah aliran sungai/DAS) in North Sumatra and Aceh, namely the Wampu and Singkil Watersheds and is also classified as a watershed that must be restored $[5,6]$. Relocation area has a dominant topography of sloping to wavy (slope of 8-15\%) as much as $66.19 \%$ of the total relocation area, flat to sloping ( $0.8 \%$ slope) as much as 33.99 of the land area and the remaining $0.81 \%$ with hilly topography with a slope of $15-25 \%[5,6]$.

Based on the characteristics of the land in the relocation area, it is important to conduct a study to find out the daily activities of the community whether it is in line or in harmony with local environmental conditions, because the practices and ways of interacting with the environment will affect the sustainability of a community's life.

Every area has their own the sustainability level of the community, so every development that will occur also requires detailed level of information, continuity, weakness, as well as the strength that each area has [7]. In relation to the achievement of the target sustainable development goals (SDG's) No. 15, namely protect, restore and promote sustainable use of terrestrial ecosystems, sustainably manage forests, combat desertification, and halt and reverse land degradation and halt biodiversity loss.

The purpose of this research is to analyze the sustainability level of the community resettlement from the Mount Sinabung eruption. To analyze the level of sustainability, use a tool called Community Sustainability Assessment/CSA developed by the Global Ecovillage Network/GEN $[8,9]$. GEN is a global association of people dedicated to sustainable living. GEN develops a concept of how to audit sustainability to provide a basis for assessing an existing individuals, rural areas and communities to compare their current status with the ideal goals of ecological, social and spiritual sustainability $[8,9]$. The results of this study can provide an input to a relevant stakeholders and the public about the development of community sustainability programs in the Siosar.

\section{Material and method}

The research data collection was done by collecting secondary data, interviews and questionnaire surveys using CSA questionnaires with a sample of 37 head of families representing the predetermined community. Assessment of the level of community sustainability is analyzed by examining the comformity with the ecovillage concept and condition of community sustainability from three aspects, namely ecological, social and spiritual aspects. Each aspect has seven benchmarks to determine the level of sustainability. The values of each parameter are summed according to the CSA questionnaire criteria. After all values are obtained, the results of each aspect are added. From the total value obtained from the sum of values for each aspect parameter, the level of sustainability of the community in the Siosar relocation area will be known. 


\section{Result and discussion}

Based on the results of the analysis of the data obtained from the kuesinone CSA (Table 1 and Table 2), the achievement of the total value of each aspect is 523 which means showing a good start towards sustainability. However, when viewed from each aspect, the ecological aspect with a low value is 139 when compared to the other two aspects and shows the need for action in achieving sustainability. The social aspect obtained 208 values and spiritual aspects obtained 176 values, which shows that the people in the Siosar relocation area showed a good start towards sustainability.

\subsection{The level of community sustainability on ecological aspect}

The results of data analysis using the CSA questionnaire for ecological aspects reached 139 (Table.1 and Table.2) which indicates the need for action to achieve sustainability. From the results of the assessment, it was acknowledged that of the seven parameters, three parameters which are: parameter water (source, quality and usage pattern); physical infrastructur, buildings and transportation; and energy sources and uses which showed a good start towards sustainability. The other four parameters are still low and need action to achieve sustainability is the parameter of sense of place, food availability production and distribution, consumption patterns and solid waste management, and waste water dan water pollution management

The value of sense of place parameter is still low due to the level of community activity in efforts to conserve or manage biological resources to ensure human survival in the present and future and the conservation of soil and water has not been carried out by the community. At the research location food availability production and distribution indicate the need for action to achieve sustainability because: (1) foodstuffs are still imported from outside the region, especially for rice and side dishes; (2) The use of chemicals in food production is still high; (3) The farmers still depend on hybrid seeds. At the research location consumption patterns and solid waste management show the need to take an action to achieve sustainability, because: (1) the majority of people do not know the concept of waste and recycling management and are still reluctant to sort out household waste (2) the building of Integrated Waste Management / TPST until now it has not been used because it has not been handed over administratively. At the research location, the parameters of waste water dan water pollution management showed the lowest value, because there was no community effort in managing household wastewater either from human waste or waste from the kitchen and bathroom.

\subsection{The level of community sustainability on social aspect}

The results of achieving the value of data analysis on the social aspects reached 208 (Table.1 and Table.2) which means that the people in the Siosar relocation area in the social aspect showed a good start towards sustainability. The assessment results show four parameters, which are: openness trust, security, shared space; communication ( the flow of ideas and information); social sustainability; health care showing a good start towards sustainability. While the value of the other three parameters, which are: networking outreach and services; education; sustainability economic (healthy local economic) shows the need for action to achieve sustainability. Assessment of networking outreach and services parameters at the research location indicates the need for action to achieve the sustainability because community members provide services only for inside the community not outside the community. At the research location it is also rare to see opportunities to collaborate with organizations outside the community, but the relationship is limited to 
training that ends and is not sustainable (there is a time limit). Educational parameters at the research location indicate the need for an action towards sustainability because the availability of educational facilities for junior high school and senior high school levels are none. In the parameters of sustainability economic (healthy local economic) shows the need for action to achieve sustainability because community economic activities have not been able to build sustainable local economic power. Most residents depend on the agricultural sector, while the 0.5 hectare agricultural land, according to Siosar residents, cannot be relied on especially because the land is infertile compared to the residents' land in the residence before being relocated. Cooperatives at the research location to support the economic activities of the residents in the three villages have not been running properly, the cooperative is only an empty building that has not been used by the residents. This local market has not functioned optimally, only active on Sundays, and those who make transactions are visitors who are on vacation at Siosar. The access to capital assistance at the research location is still small.

Table 1. The level of community sustainability is based on ecological aspects, social aspects \& spiritual aspects.

\begin{tabular}{|c|l|}
\hline Parameter & Score \\
\hline Ecological Aspect & \\
1. Sense of Place & 20 \\
2. Food Availability, Production \& Distribution & 11 \\
3. Physical Infrastructure, Buildings \& Transportation & 26 \\
4. Consumption Patterns \& Solid Waste Management & 17 \\
5. Water - sources, quality \& use patterns & 38 \\
6. Waste Water \& Water Pollution Management & -1 \\
7. Energy Sources \& Uses & 28 \\
Total Point fo the Ecological Aspect & $\mathbf{1 3 9}$ \\
\hline Social Aspect & \\
1. Openness, Trust \& Safety; Communal Space & 52 \\
2. Communication - the flow of ideas \& information & 35 \\
3. Networking Outreach \& Services & 20 \\
4. Social Sustainability & 38 \\
5. Education & 17 \\
6. Health Care & 36 \\
7. Sustainable Economics - healthy local economy & 10 \\
Total Point fo the Social Aspect & $\mathbf{2 0 8}$ \\
\hline Spiritual Aspect & 22 \\
1. Cultural Sustainability & 9 \\
2. Arts \& Leisure & 45 \\
3. Spiritual Sustainability & 32 \\
4. Community Glue & 21 \\
5. Community Resilience & $\mathbf{1 7 6}$ \\
6. A New Holographic, Circulatory World View & $\mathbf{5 2 3}$ \\
7. Peace \& Global Consciousness & \\
Total points for the Spiritual Aspect & \\
\hline Total All Aspek & \\
\hline
\end{tabular}


Table 2. Score and community sustainability condition.

\begin{tabular}{|l|l|l|}
\hline Asessment Level & Score & Sustainability Conditions \\
\hline \multirow{3}{*}{ Parameter } & 50 & Indicates excellent progress toward sustainability \\
& $25-49$ & Indicates a good start toward sustainability \\
& $0-25$ & Indicates actions are needed to undertake sustainability \\
\hline \multirow{3}{*}{ Aspect (A,B,C) } & $333+$ & Indicates excellent progress toward sustainability \\
& $166-332$ & Indicates a good start toward sustainability \\
& $0-165$ & Indicates actions are needed to undertake sustainability \\
\hline \multirow{3}{*}{ Total All Asoek (T) } & $999+$ & Indicates excellent progress toward sustainability \\
& $500-996$ & Indicates a good start toward sustainability \\
& $0-449$ & Indicates actions are needed to undertake sustainability \\
\hline
\end{tabular}

\subsection{The level of community sustainability on spiritual aspect}

The results of the achievement of the value of data analysis on the spiritual aspect reached 176 (Table.1 and Table.2) which means that the people in the Siosar relocation area, in the spiritual aspect, showed a good start towards sustainability. The results of the assessment show that three parameters which are: spiritual sustainability; community glue; a new holographic, circulation world view showing a good start towards sustainability and four parameter with low values that need action to achieve sustainability. While the value of the other three parameters, which are: cultural sustainability; art and leisure; community resilience; peace and global consciousness shows the need for action to achieve sustainability. The cultural sustainability parameter at the research location shows the need for action to achieve sustainability because cultural exchange program are none, community efforts to preserve cultural heritage cultural heritage (values, handicraft, oral tradition/stories, ritual tradition) are still minimal. Art and leisure parameters at the research location showed low scores because: (1) In the research location there were also no art groups active in carrying out artistic activities; (2) Arts and cultural performances are also rare or not routinely held in the research location; (3) The majority of people in the research sites also do not engage in activities of a fun nature such as sports and recreation, all of this are because the residents are busy farming crops from the morning until the afternoon. Free time is only available at night which is used by residents to gather and socialize among residents in the stalls in three villages; (4) Opportunities for the community members to develop their talent are limited. The community resilience parameter shows the need for action to achieve sustainability because the community has not been able to change existing conditions into opportunities to develop themselves. The results of the assessment on the parameters of peace and global consciousness show the need for action to achieve sustainability because lack of knowledge about global environmental conditions and the need for contributions by every community member to maintain environmental sustainability.

From the results of the assessment, it is important to improve the resiliency of communities to achieve sustainability through: (1) providing knowledge and practical education regarding sustainability environment because increasing education of the society will affect the level of community welfare and can prevent and reduce environmental damage; (2) increasing local economic, educational facilities, community health, art and cultural heritage. 


\section{Conclusion}

The sustainability level of the community in the Siosar relocation area shows a good start towards sustainability, specifically score in ecological aspect is lower than social and spiritual aspect, and shows the need an action to achieve sustainability.

\section{References}

1. A. Sukarna, P. Perangin, Sinabung 33210 Doa dan Harapan (Change Publication, Jakarta, 2016)

2. R. Olshansky, S. Chang, Planning for Disaster Recovery: Emerging Research Needs And Challenge Progress in Planning (2009)

3. J. Twigg, Disaster Risk Reduction. Overseas Development Institute, United Kingdom (2015)

4. Anonim, Rencana Aksi Rehabilitasi dan Rekonstruksi Pascabencana Erupsi Gunungapi Sinabung Tahun 2015-2017 (Badan Nasional Penanggulangan Bencana, Jakarta, 2015)

5. Sukarman, E. Suryani, A. Dariah, M. Anda, E. Pratiwi, L.N. Nurida, D. Sutono, Erfandi, Kasno, Las, Penanganan Lahan Relokasi Pengungsi Sinabung Di Siosar, Kabupaten Karo, Sumatera Utara (Badan Penelitian dan Pengembangan Pertanian, Jakarta, 2015)

6. A. Rauf, Rahmawaty, H. Wijoyo, Jurnal Pertanian Tropik 8, 41-53 (2015)

7. E.E. Nurlaelih, Model Ecovillage Dalam Pengelolaan Landskap Perkampungan Tradisional, https://fp.ub.ac.id/kepegawaian/wp-content/uploads/2012/05/ModelEcovilage-Euis.pdf (2011)

8. R. Gilman, The Ecovillage Challenge: The Challenge Of Developing A Community Living In Balanced Harmony - With Itself As Well As Nature - Is Tough, Context Institute: http://www.context.org/iclib/ic29/gilman1/ (1991)

9. Global Ecovillage Network, Community Sustainability Assesment, http://gen.ecovillage org/activities/index.html (2007) 